\title{
Incidence of Urinary Tract Infection (UTI) among Antenatal Patients Attending Tertiary Care Hospital
}

\author{
Naveed Altaf ${ }^{1}$, K.S. Saraswathi ${ }^{2}$ and R. Shyamala ${ }^{3^{*}}$ \\ ${ }^{1}$ Department of Pharmacology, Shadan Institute of Medical Sciences and Research Centre, \\ Hyderabad 500008, Telangana State, India \\ ${ }^{2}$ Department of Obstetrics and Gynaecology, Shadan Institute of Medical Sciences and Research \\ Centre, Hyderabad 500008, Telangana State, India \\ ${ }^{3}$ Department of Microbiology, Malla reddy Medical College for Women, Hyderabad, \\ Telangana state, India \\ *Corresponding author
}

A B S T R A C T

\begin{tabular}{|l|}
\hline Ke y w o r d s \\
$\begin{array}{l}\text { UTI, Patients, } \\
\text { Tertiary care } \\
\text { hospital. }\end{array}$ \\
\hline Article Info \\
\hline $\begin{array}{l}\text { Accepted: } \\
\text { 21 August } 2017 \\
\text { Available Online: } \\
\text { 10 September } 2017\end{array}$ \\
\hline
\end{tabular}

The aim of this study was to determine the incidence of urinary tract infection among patients attending our hospital viz., Shadan Institute of Medical Sciences and Research Centre. Urinary tract infection is very common, more than 10 million cases per year in India. The study was conducted among the pregnant women attending the Shadan Institute of Medical Sciences and Research Centre Hyderabad, from the period January 2016 to December 2016. A total of 930 urine samples were examined, 276 were found to contain significant bacteriuria, urine microscopy revealed $>10$ pus cells/ high power field. The incidence of UTI in pregnant women was found in 276 samples (30\%). In this study the most common bacteria causing urinary tract infection is Escherichia coli. This study shows the need to raise awareness of UTI and to increase the services for preventing UTI during pregnancy by maintaining proper hygienic conditions.

\section{Introduction}

Incidence of UTI is higher in women than men, $40 \%$ to $50 \%$ of whom will suffer at least one clinical episode during lifetime (Leigh et al., 1990). The increased risk factor for UTI in women may be due to short urethra, absence of prostatic secretions, pregnancy and easy contamination of urinary tract with faecal flora (Awaness et al., 2000). Approximately $90 \%$ of pregnant women develop ureteral dilation, which will persist until delivery and it may contribute to increased urinary stasis and ureterovesical reflux. UTIs are the most common bacterial infections during pregnancy. The physiological increase in plasma volume during pregnancy decreases urine concentration and up to $70 \%$ of pregnant women develop glycosuria, which is considered to increase bacterial growth in the urine (Delzell and Lefevre, 2000; Patterson and Andriole, 1987). 
Thus UTIs are the most common bacterial infections during pregnancy. Women with a history of UTIs are at increased risk of having a UTI during pregnancy and other risk factors for UTIs during pregnancy include lower socioeconomic status, individual hygiene, sickle cell trait and anaemia, increased parity or age and lack of antenatal care. The functional urinary tract abnormalities and diabetes mellitus can also increase susceptibility to UTIs during pregnancy (Nowiciki, 2002). Infections particularly in pregnancy and in elderly may be asymptomatic, if the UTIs are untreated during pregnancy the risk for pyelonephritis, cystitis, pre term delivery and foetal mortality is increased from 20 to $40 \%$. Asymptomatic Bacteriuria doubles the risk for preterm labour; and low birth weight and fetal mortality. Escherichia coli accounts for 80 to 90\% infections (Hart et al., 1996), about 85\% of community acquired UTIs and causes 50\% of nosocomial UTIs (Bergerson, 1995).

Escherichia coli may be endogenous flora of the colon, they colonise in the vaginal introitus and the periurethral area; then ascend to the bladder and then to the renal pelvis by a receptor mediated ascending process (Nowiciki, 2002). The Escherichia coli liberate a cytotoxin which elicits damage to the kidney epithelium (Guyer et al., 2002). The next common organism causing UTI is Klebsiella accounts for $6 \%$ to $17 \%$ of all nosocomial UTIs. Other organisms causing UTI are Proteus mirabilis especially in patients with long term catheters in situ. It is important to identify UTI infection by prompt screening and treatment for asymptomatic bacteriuria during pregnancy which is very useful in preventing other complications to both mother and foetus.

\section{Materials and Methods}

The study was conducted among the pregnant women attending the Shadan Institute of
Medical Sciences and Research Centre Hyderabad from the period January 2016 to December 2016. Freshly voided midstream urine samples were collected in a sterile container. These patients complained of symptoms of UTI. All urine samples were processed within $1 \mathrm{hr}$ after collection for aerobic bacterial culture.

Urine samples received at the Microbiology laboratory were plated on MacConkey and Blood agar plates, incubated at 37 degree $\mathrm{C}$ for 48 hours. Identification of pure isolates was done by observing morphological, cultural and biochemical characters. The method used in identification and characterisation of isolated bacteria included Gram staining, motility test and biochemical tests like, TSI and IMViC according to Cheesbrough (Cheesbrough, 2002). Antibiotic sensitivity testing was performed using the Kirby-Bauer disc diffusion method according to the Clinical and laboratory Standards Institute Guidelines (Gales et al., 1998).

\section{Results and Discussion}

A total of 930 urine samples were examined, 276 were found to contain significant bacteriuria, urine microscopy revealed $>10$ pus cells/ high power field. The incidence of UTI in pregnant women was found in 276 samples $(30 \%)$. Urinary tract infection is highest i.e., 54\% among 26 to 30 years of age group among the patients. $25 \%$ of UTI is seen in the age group of 16 to 20 years. $21 \%$ of UTI is seen in the age group of 21-25 years.

Among the bacterial isolates from 930 urine samples, majority of the isolates were from gram negative bacteria which includes Escherichia coli, Klebsiella species, Proteus species, Pseudomonas species.

Out of 276 samples which were positive for culture. 
Number of positive samples for Escherichia coli are $182(65.9 \%) .69$ samples (25\%) have shown Klebsiella species. 16 samples $(5.7 \%)$ have shown Proteus species. 6 samples (2.17\%) have shown Pseudomonas species.3 samples (1.08\%) have shown Staphylococcus aureus.
UTI are the most common infections encountered during pregnancy. Bacteriuria is common in pregnancy - either symptomatic or asymptomatic.

Asymptomatic bacteriuria will lead to acute pyelonephritis, if left untreated in 20 to $30 \%$ of patients (Kass et al., 1962).

\section{Incidence of UTI in relation to age distribution in Antenatal women}

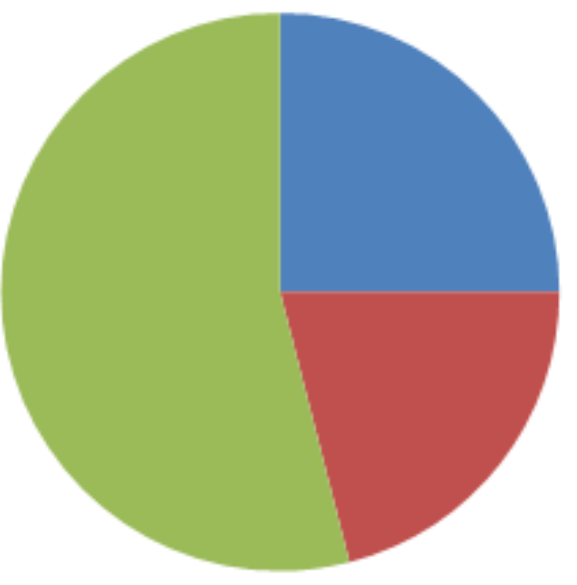

" 16 - 20years

"21-25years

26-30years

\section{Aetiology of Uti in a Tertiary care hospital}

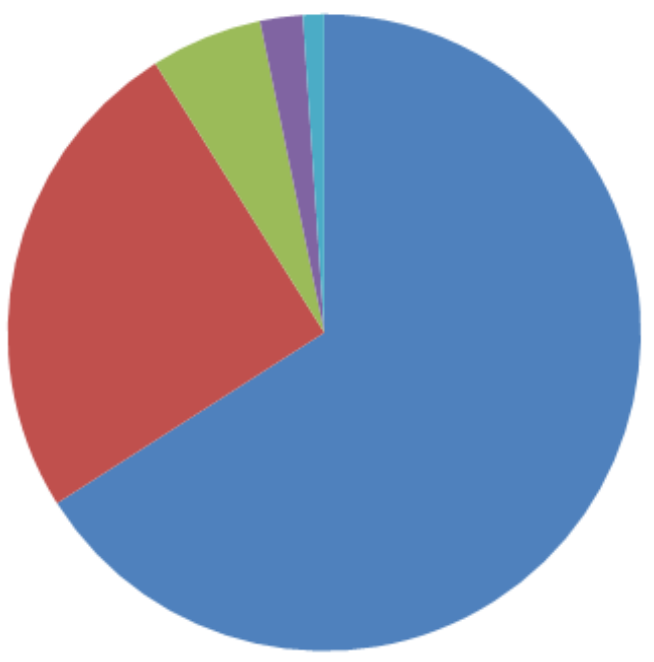

Escherichia coli

Klebsiella species

- Proteus species

- Pseudomonas species

S.aureus 
This study shows that, $30 \%$ patients in our study showed positive culture for bacteria. In relation to parity IIIrd gravida had the highest incidence rate.

Pregnant women are more susceptible to UTI because of increased urinary content of vitamins, aminoacids, and other nutrients, which encourage the persistence of infection (Asscher et al., 1966). Most of pregnant women develop glycosuria which is considered to increase bacterial growth in urine (Delzell and Lefevre, 2000).

However, the prevalence rate of UTI in pregnant women has been different in other countries like $38 \%$ in Iran, $28.5 \%$ in Pakistan, and $10.6 \%$ in Turkey. Reports from India on the incidence of UTIs in the non-pregnant women vary from 10-40\% from Aligarh $10.8 \%$ (Akram et al., 2007), 16.3\% from Tamilnadu (Mahesh et al., 2010) and 40.4\% from Imphal, Manipur (Yengkopam et al., 2007).

UTI in pregnancy is associated with significant morbidity for both mother and baby. Our study revealed the incidence rate of $30 \%$. This study also observed that Escherichia coli was the most frequently isolated organism. This study shows the need to raise awareness of UTI and to increase the services for preventing UTI during pregnancy by maintaining proper hygienic conditions.

\section{References}

Akram, M., et al., Aetiology and Antibiotic Resistance Patterns of Community Acqquired Urinary Tract Infections in JNMC Hospital Aligarh, India, Annals of Clinical Microbiology and Antimicrobials, Vol. 6, 2007, pp. 4-10.

Asscher, A.W., et al., Urine as a medium for Bacterial Growth, The Lancet, Vol.288, No 7472, 1966, pp.1037-10411.
Awaness, A.M., M.G. Al-Saadi, et al., Antibiotics Resistance in Recurrent Urinary Tract Infection, Kufa Medical Journal, Vol. 3, 2000.

Bergerson, M.G., Treatment of Pyelonephritis in Adults. Medical Clinics of North America, Vol 75, 1995, pp.619-649.

Cheesbrough, M., Medical Laboratories Manual for Tropical Countries, Butterworth-Heinemann, Cambridge, 2002.

Cheesebrough, M., District Laboratories Manual for Tropical Countries, Cambridge University Press, Cambridge, 2004.

Delzell, J.E., Jr. and M.L. Lefevre, Urinary Tract Infections during Pregnancy, American Family Physician, Vol.61, 2000, pp.713-720.

Gales, C.A., et al., Activity and spectrum of 22 antimicrobial Agents Tested against Urinary Tract Infection Pathogens in Hospitalised Patients in Latin America: Reports from the Second Year of the SENTRY Antimicrobial Surveillance Program (1998), Journal of Antimicrobial Chemotherapy, Vol. 45, No 3, pp. 293-303.

Guyer, D.M., et al., Salt the Secreted Autotransporter Toxin of Uropathogenic Escherichia coli, Is a Vacuolating Cytotoxin for Bladder and Kidney Epithelial Cells. Infection and Immunity, Vol.70, No 8, 2002, pp. 4539-4546.

Hart, A., et al., Gestational Pyelonephritis Associated Escherichia coli Isolates Represent Non- random closely Related Population, American Journal of Obstetrics and Gynecology, Vol. 1748, No.3, 1996, pp. 983-989.

Kass, D.M., Pyelonephritis and Bacteriuria. Major Problem in Preventive Medicine, Annals of Internal Medicine, Vol. 56, No. 1, 1962, 46-53.

Leigh D., Urinary Tract Infections, In 
G.R.Smith and S.F. Easma Charles, Eds., Topley and Wilson's Principles of Bacteriology, Virology and Immunity, Butler and Tanler Ltd., Frome and London, 1990, pp.197-214.

Mahesh, E., et al., Complicated Urinary Tract Infection in a Tertiary care Centre in South India, Al Ameen Journal of Medical science, Vol 3, No. 2, 2010, pp.120-127.

Nowiciki, B. Urinary Tract Infections in Pregnant Women: Old Dogmas and Current Concepts Regarding pathogenesis. Current Infectious Disease Reports, Vol 4, No 6, 2002, pp.529-535.

Patterson, T.F., and V.T. Andriole, Bacteriuria in Pregnancy, Infectious Disease Clinics of North America, Vol 111, 1987, pp.807-822.

Yengkokpam, C., et al., Antibiotic susceptibility Pattern of Urinary Isolates in Imphal (Manipur), India, Nepal Medical College Journal, Vol. 9, No. 3, 2007, pp.170-172.

\section{How to cite this article:}

Naveed Altaf, K.S. Saraswathi and Shyamala, R. 2017. Incidence of Urinary Tract Infection (UTI) among Antenatal Patients Attending Tertiary Care Hospital. Int.J.Curr.Microbiol.App.Sci. 6(9): 2092-2096. doi: https://doi.org/10.20546/ijcmas.2017.609.257 